Bartın University Journal of Faculty of Education, 8(2), 507-523

Bartın Üniversitesi Eğitim Fakültesi Dergisi, 8(2), 507-523

buefad.bartin.edu.tr

\title{
Music Performance Anxiety Levels of Students in the Music Education Graduate Program (Ankara-Gazi University Sample)
}

\author{
Ceren DOĞAN*a, Belir TECIMER ${ }^{\mathrm{b}}$
}

\begin{tabular}{l} 
Article Info \\
\hline DOI: $10.14686 /$ buefad.435272 \\
\hline Article History: \\
Received 21.06.2018 \\
Accepted $\quad 19.02 .2019$ \\
Published $\quad 30.06 .2019$ \\
\hline Keywords: \\
Music performance anxiety, \\
Applied music, \\
Instrumental performance. \\
\hline Article Type: Research Article \\
\end{tabular}

\begin{abstract}
The purpose of this study was to determine the musical performance anxiety levels of the students at Gazi University, Undergraduate Program of Music Education. It was aimed to evaluate students' negative performance perception, psychological vulnerability, somatic anxiety, personal supervision and physiological vulnerability. 110 undergraduate students were participated in the study. "Kenny Music Performance Anxiety Inventory" which was developed by Kenny in 2004 and adapted to Turkish by Tokinan in 2013 was used for data collection. The inventory consists of 25 items. The factors of the inventory were negative performance perception, psychological vulnerability, somatic anxiety, personal supervision and physiological vulnerability. For the analysis of the data, total scores of music performance anxiety and scores of sub-dimensions were calculated. Frequency and percentage values of sub-dimensions were also given in tables. As a result of the research, it was revealed that the participants have a moderate music performance anxiety. The highest level of anxiety among sub-dimensions was personal supervision. The physiological vulnerability was the secondary factor, which leads muscle tension and increases the anxiety.
\end{abstract}

\section{Müzik Öğretmenliği Lisans Programı Öğrencilerinin Müzik Performans Kaygı Düzeyleri (Ankara-Gazi Üniversitesi Örneği)}

\begin{tabular}{|c|c|}
\hline \multicolumn{2}{|c|}{ Makale Bilgisi } \\
\hline \multicolumn{2}{|c|}{ DOI: $10.14686 /$ buefad.435272 } \\
\hline \multicolumn{2}{|c|}{ Makale Geçmişi: } \\
\hline Geliş & 21.06 .2018 \\
\hline Kabul & 19.02.2019 \\
\hline Yayın & 30.06 .2019 \\
\hline \multicolumn{2}{|c|}{$\begin{array}{l}\text { Anahtar Kelimeler: } \\
\text { Müzik performans kaygısı, } \\
\text { Çalg1 eğitimi, } \\
\text { Çalg1 performansı. }\end{array}$} \\
\hline \multicolumn{2}{|c|}{$\begin{array}{l}\text { Makale Türü: Araştırma } \\
\text { Makalesi }\end{array}$} \\
\hline
\end{tabular}

\begin{abstract}
Öz
$\mathrm{Bu}$ çalışmanın amacı Gazi Üniversitesi, Müzik Öğretmenliği Ana Bilim Dalı öğrencilerinin müzik performans kaygı düzeylerini belirlemektir. Araştırma verilerini toplamak amacıyla lisans programında öğrenim gören 110 öğrenciye ulaşılmıştır. Veri toplama aracı olarak 2004'de Kenny tarafindan geliştirilen ve 2013'te Tokinan tarafindan Türkçe'ye uyarlanan "Kenny Müzik Performans Kaygısı Envanteri" kullanılmışırı. Envanter 25 maddeden oluşmaktadır. Envanterin maddeleri negatif performans algısı, psikolojik savunmasızlık, somatik kaygı, kişisel denetim ve fizyolojik savunmasılık olarak toplam beş faktörde dağılmaktadır. Verilerin analizi için ögrencilerin müzik performans kaygısı toplam puanları ve alt faktörleri toplam puanları hesaplanmıştır. Araştırma sonucunda Ankara Gazi Üniversitesi Gazi Eğitim Fakültesi Müzik Eğitimi Ana Bilim Dalı'nda 2016-2017 öğretim yılında öğrenim görmekte olan öğrencilerin müzik performansı ile ilgili orta düzeyde kaygı duyduğu ortaya çıkmıştır. Alt boyutlar içerisinde kaygı düzeyinin en yüksek görüldüğü boyut kişisel denetimdir. Ardından fizyolojik savunmasızlık alt boyutunda dile getirilmiş olunan kas gerginliği ile ortaya çıkan kaygı durumu ikinci sırada yer almaktadır.
\end{abstract}

\footnotetext{
*Corresponding Author: cdogan@bartin.edu.tr

${ }^{a}$ Asst. Prof. Dr., Bartin University, Bartin/Turkey, https://orcid.org/0000-0002-7848-0572

${ }^{b}$ Prof. Dr., Gazi University, Ankara/Turkey, https://orcid.org/0000-0001-6485-4409
} 


\section{Introduction}

The place of singing and playing instruments is quite significant in the field of professional music education. It can be considered a requirement to educate musical teacher candidates about situations that may negatively affect their musical performance. It is also a necessity to provide guidance on learning how to deal with these situations. These negative conditions may be related to the student's voice or instrument, or the physical condition of the performance environment, as well as personal thoughts and perceptions about the student's performance at the conclusion of the event. With this concern, educators at the institutions that provide professional music education play an important role for helping the student to develop a coping strategy with this problem.

The fact that individuals can benefit from the education provided at the highest level, plus be successful and happy is based on the mutual interaction of many factors. The quality of education and individual differences are at the forefront of these factors. Among the individual differences, variables such as talent, success, motivation, work habits, exam anxiety and self-esteem are prominent. These variables related to individual differences on success and psychological health may have a significant impact. Between the academic risk indicators of students especially motivation, self-esteem and test anxiety variables are noteworthy. (Bozanoglu, 2005).

According to Bloom, the behavioral goals of education can be explained by a triple classification as cognitive, mental (psycho-motor) and affective. The affective characteristics of these three types of behaviors include qualifications such as interests, values, attitudes and habits. Anxiety is also an affective trait and has an impact on human behavior. There is a relationship between affective behavior and cognitive-spiritual behaviors (Büyüköztürk, 1997). In this case, it will be appropriate to investigate the relationship between anxiety and music performance, which is an affective feature of its' cognitive and psyco-motor learning. According to Freud, anxiety is an unconscious emotion that develops in individuals' psychological structure as a result of not being able to act effectively and resist against a dangerous event (Üldaş, 2005). Işı (1996) defined anxiety as a state of wory and anxiety felt by the individual in facing a threatening situation. In broad sense, the emotional state of perceived weakness during preparation for a perceived danger is called anxiety. There are three different types of anxiety: personality, situation and incident related. Personality-related anxiety encountered as a continuous condition in some individuals as part of the individual's personality (Ellis, 1994). People who have negative cognition about themselves are also likely to evaluate themselves negatively and have higher anxiety at the time of examination (Kavakçı, Güler and Çetinkaya, 2011). Situation-related anxiety can be defined as a response to a specific situation in a given time. Incident-related anxiety is the type of anxiety that occurs in the face of a specific event (Ellis, 1994). Music performance anxiety can be stated as an incident-related anxiety type.

Symptoms of anxiety disorders come up within various ways. In addition to somatic symptoms such as tremors, heart palpitations, headache and chest congestion, it is also manifested by subjective symptoms such as the expectation that there will be very bad things, the fear of losing balance, being drowned, and fear. Anxiety disorders are subdivided into panic attacks, phobias, obsessive compulsive disorder and stress disorders. Moreover, anxiety disorders occur due to substance use or health problems (Çoban \& Kahraman, 2013).

It is necessary to distinguish the negative anxiety that makes the learning process difficult and prevents success, and the positive anxiety that causes people to achieve success above their natural actions. Positive care motivates the individual to become important in society and makes him / her willing to learn. If the anxiety is not managed well by the individual, the person will expect failure; regardless of the effort, will become a prisoner of anxiety and finally will achieve less of what he / she actually can. (Scovel, 1978).

As the anxiety level of the individual elevates, the regression with more stiff and simple behaviour may emerge. It also causes excessive focus on worry and pleasure of other individuals. In contrast, moderate anxiety has a stimulating, protective and motivating effect on the organism. In cases where anxiety is well managed, it helps the individual to work more to be successful and to take precautions against the obstacles (Akgün, Gönen and Aydın, 2007).

Considering that the anxiety of undergraduate students have been extended to the period of primary school, teachers are thought to have a role in learning how to control students' anxiety. This is only possible with teachers who learn to control their own anxiety. Students from families with authoritarian attitude are more anxious than students from families with demogratic attitude. Social skills such as the ability to build friendship can also affect the level of anxiety (Akgün, Gönen and Aydın, 2007). 
Music performance includes diverse skills such as coordination, attention, memory, aesthetics and interpretation, and motor skills (Salmon and Meyer, 1992). Music performance anxiety (MPA); a special type of performance anxiety is a fear that a potential problem that may arise during performance and the musician may fear to be negatively assessed by the audience. Physiological and psychological fear is triggered by events like a concert or a performance exam. Many musicians have discouraging experiences that suggest they will not be able to fully use their capacities. High anxiety levels lead a coaction of automatic motor reactions (Allen, 2010). Kenny (2008), who has various research in this regard, has described musical performance anxiety as a persistent, disturbing experience about performance skills to be demonstrated in front of the community, regardless of the level of ability, education or preparation of the individual.

The quality of musical performance is influenced by_physiological factors such as level of experience and sufficient preparation for performance, as well as psychological factors like self-perception, self-efficacy belief and an experience(s) of performance anxiety. The individual's sensitivity to anxiety experiences during the performance may be affected by individual characteristics such as gender, age, persistent anxiety, self-confidence, self-perception and self-efficacy. Prior to the performance, task competence, preparation and learning process of the piece, individual motivation of learning, difficulty and value of the task are related to keeping the anxiety under control. During the performance, factors such as the characteristics of the environment in which the individual is expected to perform, presence of the viewer, degree of self-disclosure, and spatial characteristics may affect the anxiety level (Papageorgi, Creech, and Welch, 2011)

MPA is a kind of anxiety that arises in the presence of the audience. Anxiety is spesifically about the performance of the performer. Symptoms may vary from performer to performer, but the main symptoms can often be listed as panic and numbness, sleeping disturbances, tremors, strained muscles, rapid breathing, sweating, increased heart rate, dry mouth, digestive problems, sadness and anxious thoughts. Despite the skill, ability, and preparation criteria, the performer may not be able to fully reflect his potential during performance due to the anxiety (Salmon, 1990). The thoughts about the perceived threat of the person performing play an important role in increasing anxiety. The high level of anxiety generally triggers by negative thinking, dislike of the audience, making mistakes and catastrophic thoughts (Salmon and Meyer, 1992).

Similar to social phobia, the idea of playing music in front of an audience can also cause concern in musicians, and can lead to intense tension resistance or avoidance. Social phobia can be described as persistent fear, including the fear of making a move that one can feel humiliated and embarrassed in situations where a person is likely to be assessed by others. Musicians with performance anxiety problems often have social phobia (Çimen, 2001).

MPA for musicians may lead to the development of a variety of medical and psychological symptoms, including general anxiety disorder and depression. As a result, individuals who experience MPA may be directed to inappropriate behaviors such as beta blockers, alcohol, and substance abuse. Moreover, according to various research, it was seen that there is a negative relationship between high level musical performance anxiety and healthy lifestyle (Doğan, 2013).

The purpose of this study was to determine the musical performance anxiety levels of the students at Gazi University, Gazi Education Faculty, Undergraduate Program of Music Education. For this purpose, it was aimed to evaluate the students' musical performance anxiety levels in terms of negative performance perception, psychological vulnerability, somatic anxiety, personal supervision and physiological vulnerability.

\section{Method}

In this section, the methodology of the research has been touched upon. The design of the research, participants, data collection tools and data analysis methods have been elucidated. Then, the limitations were specified.

\section{Research Design}

In this study, application of quantitative analysis techniques was required because of the structure of the research problems and the research purpose. In terms of time and applied method, the model of this research is a "descriptive" study. Since the participants of this study were the teacher candidates at Gazi University, Gazi Education Faculty, Undergraduate Program of Music Education, it was decided to name the study as an Ankara Sample. 


\section{Participants}

The participants of this study were the teacher candidates at Gazi University, Gazi Education Faculty, Undergraduate Program of Music Education. It was intended that the total number of 206 students in the program would participate in the study, however the data were collected from the sample of 110 students. All of the participants were taking applied music course in the spring semester of 2017. All of the participants were graduated from the high school of fine arts and in their on-going education, they were participating in piano courses in addition to their main instrument courses.

\section{Data Collection Tools}

"Kenny Music Performance Anxiety Inventory" which was developed by Kenny in 2004 and adapted to Turkish by Tokinan in 2013 was used for data collection. The Inventory of the 6th Likert type consists of 25 items. The participants were evaluated each of the statements in the scale marking one of the 6 types of expressions ranked from "strongly disagree" to "strongly agree". The factors of the inventory are negative performance perception, psychological vulnerability, somatic anxiety, personal supervision and physiological vulnerability. The Cronbach Alfa reliability coefficient of the scale is .895 and total correlations of the items are ranked from .336 to .651 .

\section{Data Collection}

The data were collected in the spring semester of 2017 at Gazi University, Gazi Education Faculty, Undergraduate Program of Music Education. Since it was intended that the total number of the students in the program would participate in the study, students in their second, fourth, sixth and eighth semesters were participated in the study. It was taken in to account that the data collection would be more effective the answers would be sincerer if the participants' needs such as hunger, thirst, taking a break should have been fulfilled, the data collection took place after lunch break. In order to apply the data collection tool of Kenny Music Performance Anxiety Inventory, 15 minutes of time were given to the students. One of the researchers was present in the data collection environment during the implementation of the tool and asked the participants to mark the closest option to the instructions in the tool. In addition, the participants were informed that their identity information would be kept confidential.

\section{Data Analysis}

In order to determine the MPA levels of the students at Gazi University, Gazi Education Faculty, Undergraduate Program of Music Education total scores of MPA were calculated. In addition, the scores of the sub-dimensions which were negative performance perception, psychological vulnerability, somatic anxiety, personal supervision and physiological vulnerability were given. Frequency and percentage values of subdimensions were also listed in tables.

This research was limited by the sub-dimensions and 25 items in the scale. In addition, the study was limited by the participants of the Gazi University, Gazi Education Faculty, Undergraduate Program of Music Education in 2017. Since the program was the only undergraduate program of music education in Ankara it was found appropriate to limit this study as Ankara sample.

\section{Findings}

In this part of the study, MPA total scores of the students and averages of scores of negative performance perception, psychological vulnerability, somatic anxiety, personal supervision and physiological vulnerability subscales were tabulated. Mode, median, standard deviation of mean, standard deviation and variance values of the data were given in Table 1. 
Table 1. Total Scores of MPA and The Sub-Factors

\begin{tabular}{lcccccc}
\hline \multirow{2}{*}{ MPA Sub-Factors } & Mean & $\begin{array}{l}\text { Standart Error } \\
\text { of The Mean }\end{array}$ & Median & Mode & $\begin{array}{c}\text { Devitation } \\
\text { Variance }\end{array}$ \\
\hline Negative Performance Perception & 2,93 & 0,09 & 2,78 & 2,36 & 0,93 & 0,86 \\
\hline Psychological Vulnerability & 3,05 & 0,10 & 3,00 & 2,88 & 0,91 & 0,83 \\
\hline Somatic Anxiety & 2,41 & 0,13 & 2,00 & 2,00 & 1,19 & 1,41 \\
\hline Personal Supervision & 2,32 & 0,12 & 2,00 & 2,00 & 1,11 & 1,20 \\
\hline Physiological Vulnerability & 2,36 & 0,13 & 2,00 & 2,00 & 1,21 & 1,47 \\
\hline Total & 2,95 & 0,92 & 2,90 & 3,00 & 0,87 & 0,75 \\
\hline
\end{tabular}

As seen in Table 1, students from Gazi University, Gazi Education Faculty, Department of Music Education were experiencing an intermediate level of musical performance. This anxiety was most apparent in the areas of personal supervision and somatic anxiety. It was also found that students also had a moderate level of anxiety regarding somatic anxiety, psychological vulnerability and negative performance perception.

The frequency, percentage, mean and standard deviation values of the first sub-factor, negative performance perception, were evaluated. The data were given in Table 2.

Table 2. Negative Performance Anxiety Sub-Factors

\begin{tabular}{|c|c|c|c|c|c|c|c|c|c|c|c|c|c|c|}
\hline \multirow{2}{*}{$\begin{array}{l}\text { Negative Performance } \\
\text { Anxiety }\end{array}$} & \multicolumn{2}{|r|}{1} & \multicolumn{2}{|r|}{2} & \multicolumn{2}{|c|}{3} & \multicolumn{2}{|c|}{4} & \multicolumn{2}{|c|}{5} & \multicolumn{2}{|c|}{6} & \multirow[b]{2}{*}{$\mathbf{x}$} & \multirow[b]{2}{*}{ SS } \\
\hline & $\mathbf{f}$ & $\%$ & f & $\%$ & $\mathbf{f}$ & $\%$ & f & $\%$ & f & $\%$ & f & $\%$ & & \\
\hline $\begin{array}{l}\text { 1. I never know if my } \\
\text { performance will be good } \\
\text { before a concert. }\end{array}$ & 10 & 11,1 & 28 & 31,1 & 15 & 16,7 & 29 & 32,2 & 5 & 5,6 & 3 & 3,3 & 3,00 & 1,27 \\
\hline $\begin{array}{l}\text { 2. My mouth feels dry before } \\
\text { or during a performance. }\end{array}$ & 16 & 14,5 & 40 & 36,4 & 18 & 16,4 & 26 & 23,6 & 2 & 1,8 & 8 & 7,3 & 2,84 & 1,38 \\
\hline $\begin{array}{l}\text { 3. I feel nausiated or dizzy } \\
\text { before or during a } \\
\text { performance. }\end{array}$ & 7 & 6,4 & 22 & 20,0 & 24 & 21,8 & 44 & 40,0 & 9 & 8,2 & 4 & 3,6 & 3,35 & 1,18 \\
\hline $\begin{array}{l}\text { 4. I often feel anxious about } \\
\text { seeing a negative reaction } \\
\text { from the listeners. }\end{array}$ & 13 & 11,8 & 39 & 35,5 & 14 & 12,7 & 30 & 27,3 & 9 & 8,2 & 5 & 4,5 & 2,98 & 1,36 \\
\hline $\begin{array}{l}\text { 5. Since the times I started } \\
\text { my music education, I } \\
\text { remember being on stage } \\
\text { worried me. }\end{array}$ & 14 & 12,7 & 45 & 40,9 & 10 & 9.1 & 29 & 26,4 & 5 & 4,5 & 7 & 6,4 & 2,88 & 1,39 \\
\hline $\begin{array}{l}\text { 6. I worry that one bad } \\
\text { performance can ruin my } \\
\text { career. }\end{array}$ & 12 & 10,9 & 21 & 19,1 & 18 & 16,4 & 43 & 39,1 & 9 & 8,2 & 7 & 6,4 & 3,34 & 1,35 \\
\hline $\begin{array}{l}\text { 7. My heartbeat accelerates } \\
\text { before or during a } \\
\text { performance. }\end{array}$ & 14 & 12,7 & 24 & 21,8 & 28 & 25,5 & 30 & 27,3 & 8 & 7,3 & 6 & 5,5 & 2,12 & 1,11 \\
\hline
\end{tabular}


Table 2 Contiuation

\begin{tabular}{lcccccccccccccc}
\hline & $\mathbf{f}$ & $\boldsymbol{\%}$ & $\mathbf{f}$ & $\boldsymbol{\%}$ & $\mathbf{f}$ & $\boldsymbol{\%}$ & $\mathbf{f}$ & $\boldsymbol{\%}$ & $\mathbf{f}$ & $\boldsymbol{\%}$ & $\mathbf{f}$ & $\%$ & $\mathbf{x}$ & $\mathbf{s S}$ \\
\hline $\begin{array}{l}\text { 8. I give up performance } \\
\text { opportunities due to concern. }\end{array}$ & 14 & 12,7 & 24 & 21,8 & 28 & 25,5 & 30 & 27,3 & 8 & 7,3 & 6 & 5,5 & 3,11 & 1,34 \\
\hline $\begin{array}{l}\text { 9. My anxiety about my } \\
\text { performance and my tension affects } \\
\text { my focus and concentration. }\end{array}$ & 17 & 15,5 & 47 & 42,7 & 21 & 19,1 & 17 & 15,5 & 4 & 3,6 & 4 & 3,6 & 2,60 & 1,23 \\
\hline $\begin{array}{l}\text { 10. Generally, I would be in a } \\
\text { disaster forecast and horror } \\
\text { preparing for a concert. }\end{array}$ & 14 & 12,7 & 24 & 21,8 & 18 & 16,4 & 39 & 35,5 & 9 & 8,2 & 6 & 5,5 & 3,20 & 1,37 \\
\hline $\begin{array}{l}\text { 11. I worry so much before } \\
\text { performance that I experience } \\
\text { insomnia. }\end{array}$ & 19 & 17,3 & 33 & 30,0 & 19 & 17,3 & 25 & 22,7 & 9 & 8,2 & 5 & 4,5 & 2,88 & 1,40 \\
\hline $\begin{array}{l}\text { 12. Before or during the } \\
\text { performance, I experience shaking, } \\
\text { shivering or chills. }\end{array}$ & 16 & 14,5 & 38 & 34,5 & 22 & 20,0 & 23 & 20,9 & 9 & 8,2 & 2 & 1,8 & 2,80 & 1,26 \\
\hline $\begin{array}{l}\text { 13. Being examined by others } \\
\text { makes me worried. }\end{array}$ & 18 & 16,4 & 30 & 27,3 & 22 & 20,0 & 29 & 26,4 & 9 & 8,2 & 2 & 1,8 & 2,88 & 1,30 \\
\hline $\begin{array}{l}\text { 14. I fear for my own judgment } \\
\text { about how my performance will be. }\end{array}$ & 16 & 14,5 & 43 & 39,1 & 22 & 20,0 & 22 & 20,0 & 5 & 4,5 & 2 & 1,8 & 2,66 & 1,20 \\
\hline
\end{tabular}

The mean scores about the students' negative performance perception were between 2.12 and 3.35 . In the inventory, students were asked to rate their opinions about expressions with 6 ratings between "I strongly disagree (1)" and "I strongly agree (6)". Averages of expressions may show that students have a moderate level of anxiety about the negative performance perception. The reason for this outcome might be that the students do not have enough information about ways to cope with performance anxiety. The statement 7 also has the lowest mean score of the scale which means that the participants with music performance axiety suffer heart beat acceleration most.

The data related to the psychological vulnerability sub-dimension are given in Table 3 .

Tablo 3. Psychological Vulnerability Sub-Factor

\begin{tabular}{|c|c|c|c|c|c|c|c|c|c|c|c|c|c|c|}
\hline \multirow[t]{2}{*}{ Psychological Vulnerability } & \multicolumn{2}{|r|}{1} & \multicolumn{2}{|r|}{2} & \multicolumn{2}{|r|}{3} & \multicolumn{2}{|r|}{4} & \multicolumn{2}{|c|}{5} & \multicolumn{2}{|c|}{6} & \multirow[b]{2}{*}{$\mathbf{x}$} & \multirow[b]{2}{*}{ SS } \\
\hline & $\mathbf{f}$ & $\%$ & $\mathbf{f}$ & $\%$ & $\mathbf{f}$ & $\%$ & f & $\%$ & $\mathbf{f}$ & $\%$ & $\mathbf{f}$ & $\%$ & & \\
\hline $\begin{array}{l}\text { 15. I often have difficulty finding } \\
\text { something to do. }\end{array}$ & 11 & 10,0 & 26 & 23,6 & 23 & 20,9 & 36 & 32,7 & 12 & 10,9 & 2 & 1,8 & 3,66 & 1,25 \\
\hline $\begin{array}{l}\text { 16. I often think there is not much } \\
\text { that life can give me. }\end{array}$ & 13 & 11,8 & 17 & 15,5 & 13 & 11,8 & 44 & 40 & 19 & 17,3 & 4 & 3,6 & 3,46 & 1,36 \\
\hline $\begin{array}{l}\text { 17. It is possible for me to make } \\
\text { mistakes even if I practise a lot while } \\
\text { getting prepared for a performance. }\end{array}$ & 23 & 20,9 & 50 & 45,5 & 10 & 9,1 & 20 & 18,2 & 5 & 4,5 & 2 & 1,8 & 2,45 & 1,24 \\
\hline $\begin{array}{l}\text { 18. I often think I'm not a worthy } \\
\text { person. }\end{array}$ & 9 & 8,2 & 18 & 16,4 & 15 & 13,6 & 41 & 37,3 & 25 & 22,7 & 2 & 1,8 & 3,55 & 1,28 \\
\hline $\begin{array}{l}\text { 19. During a performance, I find } \\
\text { myself in a state that I cannot know if } \\
\text { I would be able to complete my } \\
\text { performance. }\end{array}$ & 18 & 16,4 & 23 & 20,9 & 30 & 27,3 & 24 & 21,8 & 13 & 11,8 & 2 & 1,8 & 2,97 & 1,32 \\
\hline $\begin{array}{l}\text { 20. Thinking about the results of } \\
\text { evaluation would affect my } \\
\text { performance. }\end{array}$ & 16 & 14,5 & 42 & 38,2 & 27 & 24,4 & 13 & 11,8 & 10 & 9,1 & 2 & 1,8 & 2,68 & 1,24 \\
\hline $\begin{array}{l}\text { 21. Sometimes I feel anxious for no } \\
\text { apparent reason. }\end{array}$ & 19 & 17,3 & 47 & 42,7 & 20 & 18,2 & 18 & 16,4 & 4 & 3,6 & 2 & 1,8 & 2,52 & 1,17 \\
\hline $\begin{array}{l}\text { 22. I often think there's nothing I can } \\
\text { expect from life. }\end{array}$ & 11 & 10,0 & 18 & 16,4 & 19 & 17,3 & 34 & 30,9 & 26 & 23,6 & 2 & 1,8 & 3,47 & 1,33 \\
\hline
\end{tabular}


When the scores of the statements about psychological vulnerability were examined, it was seen that the scores changed between 2.45 and 3.66. In this case, it can be stated that the students experienced psychological vulnerability less than the anxiety about negative performance perception. In this case, the data related to psychological vulnerability with average scores given in Table 1 also supports the negative performance perception.

The frequency, percentage and mean of the subscales of somatic anxiety, self-control, and psychological vulnerability, which are the other subscales of the scale, are mentioned in Table 4.

Tablo 4. Other Sub-Factors

\begin{tabular}{|c|c|c|c|c|c|c|c|c|c|c|c|c|c|c|}
\hline \multirow[t]{2}{*}{ Sub-Factors } & \multicolumn{2}{|r|}{1} & \multicolumn{2}{|r|}{2} & \multicolumn{2}{|c|}{3} & \multicolumn{2}{|c|}{4} & \multicolumn{2}{|c|}{5} & \multicolumn{2}{|c|}{6} & \multirow[b]{2}{*}{$\mathbf{x}$} & \multirow[b]{2}{*}{ SS } \\
\hline & f & $\%$ & f & $\%$ & $\mathbf{f}$ & $\%$ & $\mathbf{f}$ & $\%$ & f & $\%$ & f & $\%$ & & \\
\hline $\begin{array}{l}\text { Somatic Anxiety } \\
\text { 23. Before or during a performance I feel } \\
\text { emotions that can be considered as panic. }\end{array}$ & 20 & 18,2 & 56 & 50,9 & 13 & 11,8 & 13 & 11,8 & 6 & 5,5 & 2 & 1,8 & 2,41 & 1,18 \\
\hline $\begin{array}{l}\text { Personal Supervision } \\
\text { 24. During a perfonmance, I feel worried } \\
\text { if I did play well. }\end{array}$ & 20 & 18,2 & 59 & 53,6 & 14 & 12,7 & 11 & 10,0 & 5 & 4,5 & 1 & 0,9 & 2,32 & 1,83 \\
\hline $\begin{array}{l}\text { Physiological Vulnerability } \\
\text { 25. Before or during a performance my } \\
\text { muscle tension increases. }\end{array}$ & 26 & 23,6 & 47 & 42,7 & 16 & 14,5 & 15 & 13,6 & 4 & 3,6 & 2 & 1,8 & 2,36 & 1,19 \\
\hline
\end{tabular}

The data in the table indicate that the students were experiencing the most intense anxiety in Personal Supervision sub-factor. Students' anxiety about playing well during performance was higher than other subdimensions. Students were worried about physiological vulnerability in the second place, and the mean score of physiological vulnerability was a little higher than personal supervision but still close. Students were anxious due to the increase in muscle tension during musical performance. In general, the anxiety levels in the three areas in the table were higher than the negative performance perception and psychological vulnerability mentioned in the previous sections.

\section{Conclusion, Discussion and Suggestions}

This research aimed to determine the music performance anxiety levels of the students at Gazi University, Department of Music Education. Within the scope of the sub-objectives of the study, music performance anxiety levels of participants were evaluated in terms of negative performance perception, psychological vulnerability, somatic anxiety, personal supervision and physiological vulnerability. This research is a descriptive study. The participants of the study were 110 teacher candidates of Gazi University, Faculty of Education, Music Education Undergraduate Program. The Kenny Music Performance Anxiety Inventory developed by Kenny in 2004 and adapted into Turkish by Tokinan in 2004 was used as data collection tool. The sixth Likert type inventory consists of 25 items. MPA total scores of the participants were calculated for data analysis. In addition, scores of subdimensions which are negative performance perception, psychological vulnerability, somatic anxiety, personal supervision and physiological vulnerability were also given. The frequency and percentage values of the subdimensions are listed in the tables.

As a result of this research, it was revealed that the students who are studying at the Gazi University Gazi Education Faculty Music Education Department during the 2016-2017 academic year have moderate level of MPA. The sub-factor with the highest level of anxiety among MPA sub-factors was personal supervision. During a performance, personal supervision base MPA may influence the cognitive functions of the student and may affect the cognitive skills such as perception and attention. This may inhibit the student from being able to cope with the slight anxiety expected to be seen during performance. Then, the anxiety situation arising from the muscle tension that is expressed in the physiological vulnerability sub-dimension comes in the second place. The possible reason for this situation is that instrumental performance requires intensive fine motor skills. With muscle tension; synchronization, intonation and velocity problems in musical performance can be expected. Coupled with the inability to control the decline in the performance, it can be expected to increase the level of anxiety.

In a qualitative research conducted by Yöndem (2012) in order to determine the physical, behavioral and cognitive characteristics of perceived performance anxiety in music students, music students' anxiety level and pre-performance readiness level were rated based on their own expressions. Participants were 17 (12 female, 5 male) university level music students. In the context analysis physical, behavioral and cognitive features were 
identified as basic themes by reviewing performance anxiety and social anxiety literature. According to the research findings, students who stated that they had higher anxiety level before the performance were experiencing physical and behavioral stress reactions more intensely. Findings related to somatic anxiety and physiological vulnerability are similar to those of this research. Participants were also found to be associated with performance anxiety, either positive or negative, of their personality traits. Negative perceptions about commission and lecturer were more common when the participants perceived their anxiety as high. This is consistent with the finding of negative performance perception in this study.

In the study of Nacakçı and Dalkıran in 2011, it was aimed to determine the anxiety level of the students from six music education departments during applied music final examination. A total of 459 students were selected as the study group. It has been observed that the vast majority of students in the study had moderate anxiety during the exams. In the case of Ankara-Gazi University, there was also a moderate level of musical performance anxiety.

By reviewing the research aimed to reduce MPA, it has been seen that psychoeducational intervention programs to reduce Musical Performance anxiety have been effective. According to the results obtained in research aiming to decrease MPA with psychoeducation program; it can be stated that the psychoeducation program was efficient to decrease the MPA. For this reason, it is more effective for students to be involved in a regular psychoeducation program. The contents of these intervention programs can be listed as behavioral interventions, cognitive strategies, cognitive behavioral approach, cognitive restraint, cognitive restructuring, relaxation techniques, biological feedback, gradual relaxation techniques, thermal biological feedback, music therapy, hypnotherapy, meditation and workgroup applications. In addition to psychotherapeutic intervention approaches, it has been observed that spiritual intervention programs such as breathing and imaginative exercises, rhythmic breathing, free improvisation and desensitization activities and yoga were also effective in controlling MPA (Doğan, 2013). In addition, Green and Gallwey (2015) pointed out that instead of concentrating on conscious processes such as correct technique, proper holding of instrument, correct breathing; concentrating on the content demanded by music by dropping itself into the flow of music, affects musical performance positively with natural flow. It may be positive to focus on music performed during a music performance in order to reduce anxiety. Thoughts should also be suspended from external factors such as the audience, concert hall, the instrument's condition, technique, musicality and intonation.

In conclusion, MPA may disturb the spiritual health if individual does not develop a coping strategy especially as it may adversely affect the professional success of the people who perform music professionally. The use of beta-blockers, substances or alcohol to reduce this anxiety that emerges at musical performance is not a solution oriented behavior. For this reason, early intervention should be provided in case of anxiety, the appropriate spiritual and psychotherapeutic approaches and expert support should be provided for ways to cope with.

Once and for all, it may be appropriate for the music educators to be informed about the MPA for their students who are studying at institutions providing professional music education. It may be advisable to give seminars on MPA in undergraduate programs of universities so that music educators and music teacher candidates are informed about ways to cope with this form of anxiety. 


\title{
Müzik Öğretmenliği Lisans Programı Öğrencilerinin Müzik Performans Kaygı Düzeyleri (Ankara-Gazi Üniversitesi Örneği)
}

\begin{abstract}
Giriş
Mesleki müzik eğitimi alanında şarkı söylemenin ve çalgı çalmanın yeri oldukça önemlidir. Bu doğrultuda, müzik öğretmeni adaylarının müzik performansı sırasında performansı olumsuz etkileyebilecek durumlar hakkında bilgilendirilmesi ve bu durumlarla baş etme yolların öğrenmesi konusunda gereken rehberliği sağlamak bir gereklilik sayılabilir. Olumsuz etki yaratacak bu durumlar, öğrencinin sesinde veya çalgısındaki problemler, ya da performansın yapılacağı ortamın fiziksel koşulları ile ilgili olabileceği gibi öğrencinin konsere çıkma durumu ile ilgili kişisel bir takım düşünceleri ve algıları sonucu ortaya çıkan sahne kaygısı ile de ilişkili olabilir. Bu kaygı ile öğrencilerin bir baş etme stratejisi geliştirebilmesi adına, mesleki müzik eğitimi veren kurumlardaki öğretim elemanlarına da önemli rol düşmektedir.
\end{abstract}

Bireylerin, sunulan eğitimden en üst düzeyde yararlanıp, başarılı ve mutlu olabilmesi, birçok etmenin karşılıklı etkileşimine dayanır. Sunulan eğitimin kalitesi ve bireysel farklılıklar, bu etmenlerin başında yer alır. Bireysel farklılıklar arasında ise yetenek, başarı, güdülenme, çalışma alışkanlıkları, sınav kaygısı, benlik saygısı gibi değişkenler öne çıkmaktadır. Başarı ve psikolojik sağlık üzerinde bireysel farklılıklar ile ilgili bu değişkenler oldukça önemli bir etkiye sahip olabilir. Öğrencilerin akademik risk göstergeleri arasında özellikle güdülenme, benlik saygısı ve sınav kaygısı değişkenleri dikkat çekmektedir. (Bozanoğlu, 2005).

Bloom'a göre eğitimin davranışsal hedefleri, bilişsel, devinsel (psiko-motor) ve duyuşsal olmak üzere üçlü bir sınıflandırma ile açıklanabilmektedir. Bu üç tür davranıştan duyuşsal özellikler ilgiler, değerler, tutumlar ve alışkanlıklar gibi nitelikleri kapsar. Kaygı da bir duyuşsal özelliktir ve insan davranışı üzerinde etkisi bulunmaktadır. Duyuşsal davranışlar ile bilişsel-devinsel davranışlar arasında ilişki bulunmaktadır (Büyüköztürk, 1997). Bu durumda, müzik performasının da içerdiği bilişsel ve devinsel öğrenmeler sebebiyle duyuşsal bir özellik olan kaygı ile ilişkisini incelemek yerinde olacaktır.

Freud'a göre kaygı, tehlikeli bir olay karsısında etkili bir davranışta bulunamama ve karşı koyma direnci gösterememe sonucu psikolojik yapıda bilinçsizce gelişen bir duygudur (Üldaş, 2005). Iş̧1k (1996) ise kaygıyı tehdit edici bir durum karşısında birey tarafindan hissedilen huzursuzluk ve endişe durumu olarak tanımlamıştır. Geniş anlamı ile sezilen bir tehlikeye hazırlanma sırasında algılanan güçsüzlük duygusunun yaşandığı duygusal bir durum olan kaygının kişilik, durum ve olay kaynaklı olmak üzere üç farklı çeşidi bulunmaktadır. Bazı bireylerde sürekli bir durum olarak karşılaşılan kişilik kaynaklı kaygı, bireyin kişiliğin parçasıdır (Ellis, 1994). Kendileri hakkında olumsuz bilişleri olan kişilerin sınav anında da kendilerini olumsuz değerlendirmeleri ve daha yüksek kaygı duymaları olasıdır (Kavakçı, Güler ve Çetinkaya, 2011). Durum kaynaklı kaygı ise belirgin bir duruma karşı belirli bir zaman içinde karşılaşılan tepki olarak tanımlanabilir. Olay kaynaklı kaygı da, belirgin olaylar karşısında ortaya çıkan kaygı türüdür (Ellis, 1994). Müzik performans kaygısının olay kaynaklı bir kaygı türü olduğu söylenebilir.

Kaygı bozukluğunun belirtileri çeşitli şekillerde kendini göstermektedir. Titreme, kalp çarpıntısı, baş ağrısı, göğüste sıkışma gibi somatik belirtilerin yanısıra çok kötü şeyler olacak beklentisi, dengeyi kaybetme korkusu, boğuluyormuş gibi olma duygusu, korkuya kapılma gibi sübjektif belirtiler ile de kendini göstermektedir. Kaygı bozuklukları panik atağı, fobiler, obsesif kompulsif bozukluk ve stres bozuklukları olarak alt bölümlere ayrılmaktadır. Ayrıca madde kullanımı ya da sağlık problemlerine bağlı olarak da kaygı bozuklukları ortaya çıkmaktadır (Çoban ve Kahraman, 2013).

Öğrenme sürecini zorlaştıran ve başarıyı engelleyen olumsuz kaygı ve kişilerin doğal edimlerinin daha üstünde başarı sağlamalarına neden olan olumlu kaygının ayırt edilmesi gerekir. Olumlu kaygı, bireyi toplum içinde önemli konumlara gelmeye motive eder ve öğrenmeye karşı istekli olmasını sağlar. Kaygı, birey tarafindan iyi yönetilmediği takdirde, kişi ne kadar çaba gösterirse göstersin başarısız olacağını hissedecek, kaygının esiri haline gelecek ve başarabileceğinin daha azını ortaya koyacaktır. (Scovel, 1978).

Bireyin kaygı düzeyinin yüksek olması daha katı, daha basit davranışlara gerilemesine, endişenmesine ve memnun etmeye aşırı odaklanmasına neden olmaktadır. Buna karşı, orta düzeydeki kaygının organizmayı uyarıcı, koruyucu ve motive edici özelliği vardır. Kaygı iyi yönetildiği durumlarda, bireyin başarılı olmak için daha fazla çalışmasına, yaşanacak olumsuzluklara karşı önlem almasına yardımcı olmaktadır (Akgün, Gönen ve Aydın, 2007). 
Üniversite öğrencilerinde var olan kaygılarının ilköğretim kademesine kadar uzandığı göz önüne alındığında kaygıları kontrol etmeyi öğrenmede aile kadar öğretmenlerin de rolü olduğu düşünülmektedir. Bu da ancak kendi kaygılarını kontrol etmeyi öğrenen öğretmenler ile mümkündür. Otoriter ailelerden gelen öğrencilerin ise demokratik ailelerden gelen öğrencilere nazaran daha çok kaygıya sahip olduğu görülmüştür. Arkadaşlık kurma becerisi gibi kişinin sosyal becerileri de kaygı düzeyini etkileyebilmektedir (Akgün, Gönen ve Aydın, 2007)

Müzik performansı; motor beceriler, koordinasyon, dikkat, bellek, estetik ve yorumlama gibi birçok beceriyi kapsamaktadır (Salmon ve Meyer, 1992). Performans kaygısının özel bir türü olan müziksel performans kaygıs1 müzisyenlerde var olan, bir başarısızlık korkusu ya da performansı sırasında meydana gelebilecek potansiyel bir problemin izleyiciler tarafindan olumsuz değerlendirilebileceği korkusudur. Örneğin bir konser veya performans sınavı gibi olayların etkisiyle, fizyolojik ve psikolojik olarak korku tetiklenir. Birçok müzisyen kapasitelerini tam olarak kullanamayacaklarını düşündüren cesaret kırıcı deneyimlere sahiptir. Çünkü kaygı düzeyleri o kadar yükselmiştir ki, otomatik motor tepkileri etkilenir (Allen, 2010). Bu konuda çok sayıda çalışması bulunan Kenny (2008) ise müziksel performans kaygısını bireyin yetenek, eğitim ve hazırlık seviyesine bağlı olmaksızın, topluluk önünde sergileyeceği performans becerileriyle ilgili ısrarcı, rahatsılılı veren endişe duygusu yaşantısı olarak tanımlamışıtır.

Müziksel performansın kalitesi, performansı sergileyen kişinin tecrübe seviyesi ve performansa yeterince hazırlıklı olmasının yanı sıra benlik algısı, öz-yeterlik inancı ve performans kaygısı deneyimi gibi psikolojik faktörlerden de etkilenir. Bireyin, performans sırasındaki kaygıyı deneyimlemedeki hassasiyeti cinsiyet, yaş, sürekli endişe, özgüven, benlik algısı ve öz-yeterlik gibi bireysel özellikleri içerebilir. Ayrıca performans öncesinde görev yeterliği ile eserin hazırlık ve öğrenme süreci, bireyin öğrenme motivasyonu, görevin zorluğu ve değeri ile kaygıyı kontrol altında tutma yolları ilişkilidir. Performans anında ise bireyin performans göstermesinin beklendiği ortamın özellikleri, izleyicinin varlığı, kendini ortaya koymanın algılanma derecesi ve mekan özellikleri gibi etkenler söz konusudur (Papageorgi, Creech, ve Welch; 2011).

Müziksel performans kaygısı (MPK), seyircinin varlığında ortaya çıkan bir kaygı türüdür. İcracı performansı ile ilgili kaygı belirtileri yaşar. Kaygı belirtileri icracıdan icracıya değişiklik gösterir fakat genellikle ana belirtiler dehşete kapılma ve panik hissi, uyku bozuklukları, titreme, kaslarda gerilme, hızlı nefes alıp verme, terleme, kalp atı̧̧ında artma, ağız kuruması, sindirim problemleri, üzüntü, endişeli düşünceler olarak sıralanabilir. Beceri, yetenek ve hazırlık ölçütlerine göre, icracı performansı hakkında kaygı yaşamasını gerektiren bir durum olmamasına rağmen, söz konusu kaygı sebebiyle performans sırasında potansiyelini tam olarak yansıtamayabilir(Salmon, 1990). Performans sergileyen kişinin tehdit algısı ile harekete geçen düşünceler, kaygı artışında önemli rol oynamaktadır. Olumsuz düşünme, beğenilmeme ve hata yapma korkusu, felaketleştirici düşünceler ve mükemmeliyetçilik ise yüksek kaygı düzeyinin içeriğini oluşturmaktadır(Salmon ve Meyer, 1992).

Sosyal fobi ile benzer olarak topluluk karşısında müzik yapma düşüncesi de müzisyenlerde kaygıya sebep olabilir ve yoğun bir gerilime karşı koyma veya sakınma durumuna yol açabilir. Sosyal fobi kişinin başkaları tarafından olası bir incelemeye alındığı durumlarda kendini aşağılanmış ve utandırılmış hissedebileceği bir hareket yapabilme korkularını da kapsayan ısrarlı bir korku olarak tanımlanabilir. Sahne kaygısı sorunu olan müzisyenlerde genellikle topluluk önüne çımaya ilişkin sosyal fobi de görülmektedir (Çimen, 2001).

Müzisyenler için MPK, genel kaygı bozukluğu ve depresyon da dahil olmak üzere çeşitli medikal ve psikolojik belirtilerin gelişmesine neden olabilir. Sonuç olarak MPK yaşayan bireyler, beta bloker kullanımı, alkol, madde kullanımı gibi uygun olmayan başa çıkma davranışlarına yönelebilmektedirler. Ayrıca çeşitli araştırmalara göre, yüksek düzeyde müziksel performans kaygısı ile sağlıklı yaşam tarzı arasında olumsuz bir ilişki olduğu görülmektedir (Doğan, 2013). İşlevsel olmayan başa çıkma stratejileri içerisinde, en dikkate alınması gereken doktor kontrolü olmaksızın ilaç kullanımıdır. Gerek uygulamacıların, gerekse araştırmacıların ve eğitimcilerin yüksek performans kaygısı yaşayan müzisyenlerde kontrolsüz ilaç kullanımı olasılığını göz ardı etmemelidirler (Çırakoğlu, 2013).

MPK her düzeyde müziksel performans sergileyen kişileri etkilemektedir. Müzik eğitimcilerinin öğrencilerini bir performansa hazırlarken onların kaygı düzeylerini ve bu kaygının altında yatan sebepleri saptamaları, öğrencinin performans kalitesinin yükselmesinde etkili olabilir. Performans kaygısının fizyolojik, bilişsel ve psikolojik nedenlerini irdelemek ögrenci ve eğitimcilerin altta yatan sorunları gidermeye yönelik çalışmalar yapmasına olanak sağlayabilir. Bu gerekçeler doğrultusunda yapılan bu çalışmanın amacı "Gazi Üniversitesi Müzik Eğitimi Ana Bilim Dalı öğrencilerinin müzik performans kaygı düzeylerini belirlemektir. Bu amaç doğrultusunda, 
öğrencilerin müzik performans kaygı düzeylerinin negatif performans algısı, psikolojik savunmasızlık, somatik kaygı, kişisel denetim ve fizyolojik savunmasızlık açısından değerlendirilmesi hedeflenmektedir.

\section{Yöntem}

Bu bölümde araştırmanın metodolojisi ortaya konulmuştur. Çalışma grubu, araştırmada kullanılan veri toplama aracı ve veri analizi yöntemleri hakkında bilgi verilmiştir. Daha sonra, sınırlamalar belirtilmiştir.

\section{Araştırma Modeli}

$\mathrm{Bu}$ çalışmada, araştırma probleminin yapısı ve araştırmanın amacı nedeniyle, nicel analiz tekniklerinin uygulanmasına karar verilmiştir. Zaman ve uygulanan yöntem açısından, bu araştırmanın modeli betimsel çalışmadır. Araştırmanın katılımcıları Gazi Üniversitesi Gazi Eğitim Fakültesi Müzik Eğitimi Lisans Programı öğretmen adayları olması sebebiyle bu çalışma Ankara örneği olarak adlandırılmıştır.

\section{Katılımelar}

Araştırmanın katılımcıları, Gazi Üniversitesi Gazi Eğitim Fakültesi Müzik Eğitimi Lisans Programında öğrenim gören öğretmen adaylarıdır. Programda yer alan toplam 206 öğrencinin çalışmaya katılması amaçlanmış, ancak 110 öğrenciye ulaşılabilmiştir. Tüm katılımcılar, 2017 bahar döneminde çalgı derslerine devam etmekte olup katılımcıların tamamı güzel sanatlar lisesinden mezun olmuşlar ve devam eden eğitimlerinde ana çalgı derslerine ek olarak piyano derslerine de katılmaktadırlar.

\section{Veri Toplama Araçları}

2004 yılında Kenny tarafindan geliştirilen ve 2013 yılında Tokinan tarafından Türkçe'ye uyarlanan "Kenny Müzik Performansı Kaygı Envanteri”, veri toplama aracı olarak kullanılmıştır. Altılı Likert tipi envanter 25 maddeden oluşmaktadır. Ölçekte yer alan ifadelere katılma oranı "kesinlikle katılmıyorum" ile "kesinlikle katılıyorum" arasında değişen rakamları işaretleyerek belirlenmektedir. Envanterin maddeleri negatif performans algısı, psikolojik savunmasızlık, somatik kaygı, kişisel denetim ve fizyolojik savunmasızlık olarak toplam beş faktörde dağılmaktadır. Ölçeğin Cronbach Alfa güvenirlik katsayısı $.895^{`}$ dir. ve maddelerin madde toplam korelasyonlar1 .336 ile .651 arasında değişmektedir.

\section{Verilerin Toplanması}

Veriler, Gazi Üniversitesi Gazi Eğitim Fakültesi Müzik Eğitimi Lisans Programı'nda 2017 bahar döneminde toplanmıştır. Programda yer alan toplam öğrenci sayısının araştırmaya katılması amaçlandığından, araştırmaya ikinci, dördüncü, altıncı ve sekizinci dönem öğrencileri katılmıştır. Katılımcıların açlık, susuzluk, mola gibi ihtiyaçlarının karşılanmış olması halinde daha verimli bir veri toplama gerçekleştirileceği ve daha içten cevaplar alınabileceği dikkate alınarak, veri toplama işlemi öğle tatilinden sonra, ders başlangıcından önce gerçekleştirilmiştir. Veri toplama aracı olan Kenny Müzik Performansı Kaygı Envanterinin öğrenciler tarafindan doldurulması için 15 dakika süre verilmiştir. Aracın uygulanma sürecinde araştırmacılardan biri veri toplama ortamında bulunmuş, katılımcılardan araçta yer alan sorular için kendilerine en yakın gelen seçeneği işaretlemelerini istemiştir. Ayrıca katılımcılara kimlik bilgilerinin gizli tutulacağı konusunda bilgilendirme yapılmıştır.

\section{Verilerin Analizi}

Araştırmanın problem durumuyla paralel olarak Gazi Üniversitesi Gazi Eğitim Fakültesi Müzik Eğitimi Lisans Programı öğrencilerinin müziksell performans kaygı düzeylerini belirlemek amacıyla MPK toplam puanları hesaplanmıştır. Ayrıca, negatif performans algısı, psikolojik hassasiyet, somatik kaygı, kişisel denetim ve fizyolojik savunmasızlık gibi alt boyutların puanları da alt problemlerden yola çıkılarak verilmiştir. Alt boyutların frekans ve yüzde değerleri ise tablolarda listelenmiştir.

Bu araştırma, ölçeğin alt boyutları ve 25 maddesi ile sınırlıdır. Ayrıca çalışma, Gazi Üniversitesi Gazi Eğitim Fakültesi, Müzik Eğitimi Lisans Programının 2017 yılındaki öğrencileri ile sınırlandırılmıştır. Program, Ankara'da müzik öğretmeni yetiştiren tek lisans programı olduğundan, bu çalışmayı Ankara örneği olarak sınırlamak uygun görülmüş̧ür. 


\section{Bulgular}

Araştırmanın bu bölümünde öğrencilerin MPK toplam puanları ve negatif performans algısı, psikolojik savunmasızlık, somatik kaygı, kişisel denetim ve fizyolojik savunmasızlık alt faktörleri puan ortalamaları tablolar halinde verilmiştir. Mod, medyan, ortalamanın standart hatası, standart sapma ve varyans değerleri Tablo 1'dedir.

Tablo 1. MPK Toplam Puanı ve Alt Faktörlere Ait Puanlar

\begin{tabular}{|c|c|c|c|c|c|c|}
\hline MPK Alt Faktörleri & $\begin{array}{l}\text { Puan } \\
\text { Ortalaması }\end{array}$ & $\begin{array}{l}\text { Ortalamanın } \\
\text { Standart } \\
\text { Hatası }\end{array}$ & Medyan & Mod & $\begin{array}{l}\text { Standart } \\
\text { Sapma }\end{array}$ & Varyans \\
\hline Negatif performans alg1s1 & 2,93 & 0,09 & 2,78 & 2,36 & 0,93 & 0,86 \\
\hline Psikolojik savunmasızlık & 3,05 & 0,10 & 3,00 & 2,88 & 0,91 & 0,83 \\
\hline Somatik kayg1 & 2,41 & 0,13 & 2,00 & 2,00 & 1,19 & 1,41 \\
\hline Kişisel denetim & 2,32 & 0,12 & 2,00 & 2,00 & 1,11 & 1,20 \\
\hline Fizyolojik savunmasızlık & 2,36 & 0,13 & 2,00 & 2,00 & 1,21 & 1,47 \\
\hline Toplam Puan & 2,95 & 0,92 & 2,90 & 3,00 & 0,87 & 0,75 \\
\hline
\end{tabular}

Tablo 1'de görüldüğü üzere Gazi Üniversitesi, Gazi Eğitim Fakültesi, Müzik Eğitimi Ana Bilim Dalı öğrencileri orta düzeyde müzik performans kaygısı yaşamaktadırlar. Bu kaygı en yoğun olarak kişisel denetim ve somatik kaygı alanlarında görülmektedir. Ayrıca somatik kaygı, psikolojik savunmasızlık ve negatif performans algısında da öğrencilerin yine orta düzey bir kaygı yaşadığı ortaya çıkmıştır.

Birinci alt faktör olan negatif performans algısı ile ilgili frekans, yüzde, ortalama ve standart sapma değerleri irdelenmiştir. Veriler Tablo 2'de yer almaktadır.

Tablo 2. Negatif Performans Algısı Alt Faktörüne Ait Veriler

\begin{tabular}{|c|c|c|c|c|c|c|c|c|c|c|c|c|c|c|}
\hline \multirow[b]{2}{*}{ Negatif Performans Algısı } & \multicolumn{2}{|c|}{1} & \multicolumn{2}{|c|}{2} & \multicolumn{2}{|c|}{3} & \multicolumn{2}{|c|}{4} & \multicolumn{2}{|c|}{5} & \multicolumn{2}{|c|}{6} & \multirow[b]{2}{*}{$\mathbf{x}$} & \multirow[b]{2}{*}{ SS } \\
\hline & $\mathbf{f}$ & $\%$ & $\mathbf{f}$ & $\%$ & $\mathbf{f}$ & $\%$ & $\mathbf{f}$ & $\%$ & $\mathbf{f}$ & $\%$ & $\mathbf{f}$ & $\%$ & & \\
\hline $\begin{array}{l}\text { 1.Bir konser öncesinde } \\
\text { performansımın iyi olup } \\
\text { olmayacağını asla bilemem. }\end{array}$ & 10 & 11,1 & 28 & 31,1 & 15 & 16,7 & 29 & 32,2 & 5 & 5,6 & 3 & 3,3 & 3,00 & 1,27 \\
\hline $\begin{array}{l}\text { 2. Performans öncesinde ve } \\
\text { performans sırasında ağzım kurur. }\end{array}$ & 16 & 14,5 & 40 & 36,4 & 18 & 16,4 & 26 & 23,6 & 2 & 1,8 & 8 & 7,3 & 2,84 & 1,38 \\
\hline $\begin{array}{l}\text { 3. Performans öncesinde veya } \\
\text { performans sırasında midem bulanır } \\
\text { veya başım döner. }\end{array}$ & 7 & 6,4 & 22 & 20,0 & 24 & 21,8 & 44 & 40,0 & 9 & 8,2 & 4 & 3,6 & 3,35 & 1,18 \\
\hline $\begin{array}{l}\text { 4. S1k sık dinleyicilerden olumsuz } \\
\text { bir tepki görme endişesi duyarım. }\end{array}$ & 13 & 11,8 & 39 & 35,5 & 14 & 12,7 & 30 & 27,3 & 9 & 8,2 & 5 & 4,5 & 2,98 & 1,36 \\
\hline $\begin{array}{l}\text { 5. Müzik eğitimine ilk başladığım } \\
\text { zamanlardan beri sahneye çıkma } \\
\text { konusunda endişe duyduğumu } \\
\text { hatırlıyorum. }\end{array}$ & 14 & 12,7 & 45 & 40,9 & 10 & 9.1 & 29 & 26,4 & 5 & 4,5 & 7 & 6,4 & 2,88 & 1,39 \\
\hline $\begin{array}{l}6 \text { Tek bir kötü performansın } \\
\text { kariyerimi mahvedebileceğini } \\
\text { düşünerek endişelenirim. }\end{array}$ & 12 & 10,9 & 21 & 19,1 & 18 & 16,4 & 43 & 39,1 & 9 & 8,2 & 7 & 6,4 & 3,34 & 1,35 \\
\hline
\end{tabular}


Tablo 2 Devamı

\begin{tabular}{|c|c|c|c|c|c|c|c|c|c|c|c|c|c|c|}
\hline & f & $\%$ & f & $\%$ & $\mathbf{f}$ & $\%$ & f & $\%$ & f & $\%$ & f & $\%$ & $\mathbf{x}$ & SS \\
\hline $\begin{array}{l}\text { 7.Performans öncesinde veya performans } \\
\text { sırasında kalp atışlarım hızlanır ve kalbim } \\
\text { göğsümde gümbür gümbür çarpar. }\end{array}$ & 14 & 12,7 & 24 & 21,8 & 28 & 25,5 & 30 & 27,3 & 8 & 7,3 & 6 & 5,5 & 2,12 & 1,11 \\
\hline $\begin{array}{l}\text { 8. Endişe nedeniyle yapılmaya değer } \\
\text { performans firsatlarından vazgeçerim. }\end{array}$ & 14 & 12,7 & 24 & 21,8 & 28 & 25,5 & 30 & 27,3 & 8 & 7,3 & 6 & 5,5 & 3,11 & 1,34 \\
\hline $\begin{array}{l}\text { 9. Performansım hakkındaki endişem ve } \\
\text { gerginliğim, odaklanmamı ve } \\
\text { konsantrasyonumu etkiler. }\end{array}$ & 17 & 15,5 & 47 & 42,7 & 21 & 19,1 & 17 & 15,5 & 4 & 3,6 & 4 & 3,6 & 2,60 & 1,23 \\
\hline $\begin{array}{l}\text { 10. S1klıkla, bir konsere hazırlanırken bir } \\
\text { felaket beklentisi ve dehşet içinde olurum. }\end{array}$ & 14 & 12,7 & 24 & 21,8 & 18 & 16,4 & 39 & 35,5 & 9 & 8,2 & 6 & 5,5 & 3,20 & 1,37 \\
\hline $\begin{array}{l}\text { 11. Performans öncesi o kadar } \\
\text { endişelenirim ki uykum kaçar. }\end{array}$ & 19 & 17,3 & 33 & 30,0 & 19 & 17,3 & 25 & 22,7 & 9 & 8,2 & 5 & 4,5 & 2,88 & 1,40 \\
\hline $\begin{array}{l}\text { 12. Performans öncesinde veya } \\
\text { performans sırasında sarsılma, titreme ya } \\
\text { da ürperme yaşarım. }\end{array}$ & 16 & 14,5 & 38 & 34,5 & 22 & 20,0 & 23 & 20,9 & 9 & 8,2 & 2 & 1,8 & 2,80 & 1,26 \\
\hline $\begin{array}{l}\text { 13. Başkaları tarafindan incelenmek beni } \\
\text { endişelendirir. }\end{array}$ & 18 & 16,4 & 30 & 27,3 & 22 & 20,0 & 29 & 26,4 & 9 & 8,2 & 2 & 1,8 & 2,88 & 1,30 \\
\hline $\begin{array}{l}\text { 14. Performansımın nasıl olacağına dair } \\
\text { kendi yargım konusunda endişe duyarım. }\end{array}$ & 16 & 14,5 & 43 & 39,1 & 22 & 20,0 & 22 & 20,0 & 5 & 4,5 & 2 & 1,8 & 2,66 & 1,20 \\
\hline
\end{tabular}

Araştırmaya katılan öğrencilerin negatif performans algısı ifadelerine ait ortalamaları 2,12 ile 3,35 arasındadır. Envanterde öğrencilerden ifadeler ile ilgili fikirlerini "kesinlikle katılmıyorum (1)" ile "kesinlikle katılıyorum (6)" arasında 6 basamak ile derecelendirmeleri istenmiştir. İfadelere ait ortalamalar öğrencilerin negatif performans algısında orta düzeyde bir kaygı yaşadıklarını gösterebilir. Bu durumun olası sebebi öğrencilerin performans kaygısı ile başa çıkma yolları hakkında yeterli bilgi sahibi olmamasından kaynaklanabilir. Yedi numaralı madde ise puan ortalamasının ölçekte en düşük sonuç verdiği maddedir ve bu da MPK yaşayan öğrencilerin en çok kalp atışında hızlanma yaşadığına işaret edebilir.

Veri toplama aracının psikolojik savunmasızlık alt boyutu ile ilgili verilere Tablo 3'de yer verilmiştir.

Tablo 3. Psikolojik Savunmasızlık Alt Boyutuna Ait Veriler

\begin{tabular}{|c|c|c|c|c|c|c|c|c|c|c|c|c|c|c|}
\hline \multirow[t]{2}{*}{ Psikolojik Savunmasızlık } & \multicolumn{2}{|r|}{$\mathbf{1}$} & \multicolumn{2}{|c|}{2} & \multicolumn{2}{|c|}{3} & \multicolumn{2}{|r|}{4} & \multicolumn{2}{|c|}{5} & \multicolumn{2}{|c|}{6} & & \multirow[b]{2}{*}{ ss } \\
\hline & $\mathbf{f}$ & $\%$ & f & $\%$ & f & $\%$ & f & $\%$ & $\mathbf{f}$ & $\%$ & $\mathbf{f}$ & $\%$ & & \\
\hline $\begin{array}{l}\text { 15. S1k sık bir şeyler yapacak gücü bulmakta } \\
\text { zorlanırım. }\end{array}$ & 11 & 10,0 & 26 & 23,6 & 23 & 20,9 & 36 & 32,7 & 12 & 10,9 & 2 & 1,8 & 3,66 & 1,25 \\
\hline $\begin{array}{l}\text { 16. Sıkça, hayatın bana verebileceği fazla } \\
\text { birşey olmadığını düşünürüm. }\end{array}$ & 13 & 11,8 & 17 & 15,5 & 13 & 11,8 & 44 & 40 & 19 & 17,3 & 4 & 3,6 & 3,46 & 1,36 \\
\hline $\begin{array}{l}\text { 17. Bir performansa hazırlanırken çok } \\
\text { çalışsam bile hata yapmam olasıdır. }\end{array}$ & 23 & 20,9 & 50 & 45,5 & 10 & 9,1 & 20 & 18,2 & 5 & 4,5 & 2 & 1,8 & 2,45 & 1,24 \\
\hline $\begin{array}{l}\text { 18. S1k sık değerli bir insan olmadığımı } \\
\text { düşünürüm. }\end{array}$ & 9 & 8,2 & 18 & 16,4 & 15 & 13,6 & 41 & 37,3 & 25 & 22,7 & 2 & 1,8 & 3,55 & 1,28 \\
\hline $\begin{array}{l}\text { 19. Performans sırasında kendimi } \\
\text { performansımı tamamlayıp } \\
\text { tamamlayamayacağımdan emin olmayan bir } \\
\text { halde bulurum. }\end{array}$ & 18 & 16,4 & 23 & 20,9 & 30 & 27,3 & 24 & 21,8 & 13 & 11,8 & 2 & 1,8 & 2,97 & 1,32 \\
\hline $\begin{array}{l}\text { 20. Alacağım değerlendirme sonuçlarını } \\
\text { düşünmek performansımı etkiler. }\end{array}$ & 16 & 14,5 & 42 & 38,2 & 27 & 24,4 & 13 & 11,8 & 10 & 9,1 & 2 & 1,8 & 2,68 & 1,24 \\
\hline $\begin{array}{l}\text { 21. Bazen belli bir sebebi olmaksızın } \\
\text { kendimi endişeli hissederim. }\end{array}$ & 19 & 17,3 & 47 & 42,7 & 20 & 18,2 & 18 & 16,4 & 4 & 3,6 & 2 & 1,8 & 2,52 & 1,17 \\
\hline $\begin{array}{l}\text { 22. Siklıkla hayattan bekleyebileceğim } \\
\text { hiçbir şey olmadığını düşünürüm. }\end{array}$ & 11 & 10,0 & 18 & 16,4 & 19 & 17,3 & 34 & 30,9 & 26 & 23,6 & 2 & 1,8 & 3,47 & 1,33 \\
\hline
\end{tabular}


Psikolojik savunmasızlık ile ilgili ifadelerin puan ortalamaları incelendiğinde puanların 2,45 ile 3,66 arasında değiştiği görülmüştür. Bu durumda öğrencilerin psikolojik savunmasızlık ile ilgili kaygıyı negatif performans algısı ile ilgili kaygıya göre daha az yaşadığı söylenebilir. Bu durumu Tablo 1'de verilen negatif performans algısı ile psikolojik savunmasızlık puan ortalamaları ile ilgili veriler de desteklemektedir.

Ölçeğin diğer alt boyutları olan somatik kaygı, kişisel denetim ve psikolojik savunmasızlık alt boyutlarına ilişkin frekans, yüzde ve ortalama verilerine Tablo 4'de değinilmiştir.

Tablo 4. Diğer alt boyutlara ilişkin veriler

\begin{tabular}{|c|c|c|c|c|c|c|c|c|c|c|c|c|c|c|}
\hline \multirow[t]{2}{*}{ Alt Boyutlar } & \multicolumn{2}{|r|}{1} & \multicolumn{2}{|r|}{2} & \multicolumn{2}{|c|}{3} & \multicolumn{2}{|c|}{4} & \multicolumn{2}{|c|}{5} & \multicolumn{2}{|c|}{6} & \multirow[b]{2}{*}{$\mathbf{x}$} & \multirow[b]{2}{*}{ SS } \\
\hline & $\mathbf{f}$ & $\%$ & f & $\%$ & $\mathbf{f}$ & $\%$ & $\mathbf{f}$ & $\%$ & f & $\%$ & $\mathbf{f}$ & $\%$ & & \\
\hline $\begin{array}{l}\text { Somatik Kaygı: } \\
\text { 23.Performans öncesinde veya } \\
\text { performans sırasında panik } \\
\text { sayılabilecek duygular yaşarım. }\end{array}$ & 20 & 18,2 & 56 & 50,9 & 13 & 11,8 & 13 & 11,8 & 6 & 5,5 & 2 & 1,8 & 2,41 & 1,18 \\
\hline $\begin{array}{l}\text { Kişisel Denetim: } \\
\text { 24. Performans sonrasında iyi } \\
\text { çalabildim mi diye endişelenirim. }\end{array}$ & 20 & 18,2 & 59 & 53,6 & 14 & 12,7 & 11 & 10,0 & 5 & 4,5 & 1 & 0,9 & 2,32 & 1,83 \\
\hline $\begin{array}{l}\text { Fizyolojik Savunmasızlık: } \\
\text { 25. Performans öncesinde ya da } \\
\text { performans sırasında kaslarımdaki } \\
\text { gerginlik artar. }\end{array}$ & 26 & 23,6 & 47 & 42,7 & 16 & 14,5 & 15 & 13,6 & 4 & 3,6 & 2 & 1,8 & 2,36 & 1,19 \\
\hline
\end{tabular}

Elde edilen veriler göstermektedir ki öğrenciler müziksel performans kaygısını en yoğun düzeyde kişisel denetim alt boyutunda yaşamaktadırlar. Öğrencilerin performans sırasında iyi çalabilme konusundaki endişesi diğer alt boyutlara göre daha yüksek çıkmıştır. Öğrenciler ikinci sırada ise fizyolojik savunmasızlık ile ilgili kaygı yaşamaktadır, fizyolojik savunmasızlık puan ortalaması da kişisel denetimden biraz daha yüksek olmakla birlikte yine de yakın düzeydedir. Öğrenciler, müzik performansı sırasında kas gerginliklerindeki artış sebebiyle kaygı yaşamaktadır. Genel olarak irdelersek bu bölümde bahsedilen üç alandaki kaygı düzeyi önceki bölümlerde değinilmiş olunan negatif performans algısı ve psikolojik savunmasızlığa göre daha yüksektir.

\section{Sonuç, Tartışma ve Öneriler}

Bu ararştırma Gazi Üniversitesi, Müzik Eğitimi Ana Bilim Dalı öğrencilerinin müzik performans kayg1 düzeylerini belirlemeyi amaçlamıştır. Araştırmanın alt amaçları kapsamında, katılımcıların müzik performans kayg1 düzeylerinin negatif performans algısı, psikolojik savunmasızlık, somatik kaygı, kişisel denetim ve fizyolojik savunmasızlık açısından değerlendirilmesi yapılmıştır. Bu araştırma bir betimsel çalışmadır. Araştırmanın katılımcıları, 2017 bahar döneminde Gazi Üniversitesi, Gazi Eğitim Fakültesi, Müzik Eğitimi Lisans Programı'nda öğrenim gören 110 öğretmen adayıdır. Veri toplama aracı olarak, 2004 yılında Kenny tarafından geliştirilen ve 2013 yılında Tokinan tarafından Türkçe'ye uyarlanan "Kenny Müzik Performansı Kaygı Envanteri” kullanılmıştır. Altılı Likert tipindeki envanter, 25 maddeden oluşmaktadır. Veri analizi için, katılımcıların MPK toplam puanları hesaplanmıştır. Ayrıca negatif performans algısı, psikolojik hassasiyet, somatik kaygı, kişisel denetim ve fizyolojik savunmasızlık gibi alt boyutların puanları da verilmiştir. Alt boyutların frekans ve yüzde değerleri ise tablolarda listelenmiştir.

Araştırma sonucunda Ankara Gazi Üniversitesi Gazi Eğitim Fakültesi Müzik Eğitimi Ana Bilim Dalı'nda 2016-2017 öğretim yılında öğrenim görmekte olan öğrencilerin müzik performansı ile ilgili orta düzeyde kayg1 duyduğu ortaya çıkmıştır. MPK alt boyutları içerisinde kaygı düzeyinin en yüksek görüldüğü alt boyut kişisel denetimdir. Kişisel denetimin öğrencinin bilişsel fonksiyonlarını etkilemesi öğrencinin algı ve dikkat gibi bilişsel becerilerinin performans sırasında da etkilenmesine sebep olabilir. Bu durum çocukta performans sırasında görülmesi beklenen hafif düzeyde kaygıyla başa çıkmasına engel olabilir. Ardından fizyolojik savunmasızlık alt boyutunda dile getirilmiş olunan kas gerginliği ile ortaya çıkan kaygı durumu ikinci sırada yer almaktadır. Bu durumun olası sebebi çalgı performansının yoğun bir ince motor beceri gerektirmesidir. Kas gerginliği ile çalg1 performansında senkronizasyon, entonasyon ve acilite sorunlarının ortaya çıkması beklenebilecek bir durumdur. Bu etkenlerle performansın kalitesinde ortaya çıkacak düşüş de öğrencilerin kişisel denetimindeki yetersizliklerle birleştiğinde kaygı düzeyinin artması beklenebilir. 
Müzik öğrencilerinde algılanan performans kaygısının fiziksel, davranışsal ve bilişsel özelliklerini belirlemek amacıyla Yöndem (2012) tarafından yapılan nitel bir araştırmada müzik öğrencilerinin kaygı düzeyi ve performans öncesi hazırlık düzeyi kendi ifadelerine dayanarak derecelendirilmiştir. Araştırma katılımcıları, 17 (12 kadın; 5 erkek) üniversite düzeyinde müzik bölümü öğrencisidir. Yapılan içerik analizinde performans kaygısı ve sosyal kaygı literatüründen yararlanılarak kaygının bileşenleri olarak geçen fiziksel, davranışsal ve bilişsel özellikler temel temalar olarak belirlenmiştir. Araştırma bulgularına göre, performans öncesi daha fazla kaygı yaşadığını belirten öğrenciler, fiziksel ve davranışsal stres tepkilerini daha yoğun yaşamaktadır. Somatik kaygı ve fizyolojik savunmasızlık ile ilgili elde edilen bulgular da bu araştırma verileri ile benzeşmektedir. Katılımcıların kendi kişilik özelliklerine ilişkin olumlu ya da olumsuz nitelendirmelerin performans kaygısı ile ilişkilendirildiği de belirlenmiştir. Kaygısını yüksek olarak algılayanlarda, komisyona ve ders hocasına ilişkin olumsuz algılamaların ise daha yaygın olduğu bulunmuştur. Bu durum, bu araştırmada negatif performans algısına ilişkin elde edilen verilerle de tutarlılık göstermektedir.

Nacakçı ve Dalkıran 2011'de 6 üniversitedeki müzik öğretmenliği anabilim dalı öğrencilerinin bireysel çalg1 dersi sınavında içinde bulundukları kaygı düzeylerini ve bu kaygıların farklı değişkenlere göre anlamlılığını belirlemek amacıyla bir çalışma yapmıştır. Çalışma grubu olarak toplam 459 öğrenci seçilmiştir. Çalışmada öğrencilerin büyük çoğunluğunun sinavlarda orta düzeyde kaygı yaşadıkları görülmüştür. Ankara-Gazi Üniversitesi örneğinde de orta düzeyde müzik performans kaygısı görülmektedir.

MPK'nı azaltmaya yönelik yapılmış olunan araştırmalar sonucunda Müziksel Performans kaygısını azaltmaya yönelik psikoeğitim amaçlı müdahale programlarının olumlu sonuç verdiği görülmüştür. Müziksel performans kaygısının psikoeğitim programı ile azaltılmasına yönelik yapılan araştırmalarda elde edilen sonuçlara göre; psikoeğitim programının MPK azaltmadaki etkisinin artarak devam ettiği söylenebilir. Bu sebeple kaygı yaşayan öğrencilerin düzenli bir psikoeğitim programına dahil olması daha etkili olacaktır. Bu müdahale programlarının içeriği davranışsal öğeler, bilişsel stratejiler, bilişsel davranışçı yaklaşım, ipucu kontrollü gevşeme, bilişsel yeniden yapılandırma, gevşeme teknikleri, biyolojik geri bildirim, aşamalı gevşeme teknikleri, termal biyolojik geribildirim, müzik terapisi, hipnoterapi, meditasyon ve çalışma grubu uygulamaları olarak sıralanabilir. MPK'nın kontrol altına alınmasında psikoterapik müdahale yaklaşımlarının yanı sıra nefes egzersizleri, imgeleme çalışmaları, ritmik nefes alma egzersizleri, özgür doğaçlama ve duyarsızlaştırma etkinlikleri ve yoga gibi spiritüel müdahale programlarının da etkili olduğu görülmüştür (Doğan, 2013). Ayrıca Green ve Gallwey (2015), müzik performansı sırasında bireyin doğru teknik, çalgıyı doğru tutma, doğru nefes gibi bilinçli süreçlere yoğunlaşması yerine kendisini müziğin akışına bırakıp müziğin talep ettiği içeriğe yoğunlaşarak doğal bir akış ile icranın müzik performansını olumlu etkilediğine değinmektedir. Özetle, kaygıyı azaltmak adına müzik performansı sırasında icra edilen müziğe odaklanarak seyirci, konser salonu gibi dışsal etmenler ile çalgı tutuşu, müzikalite, entonasyon gibi çalgı odasında düşünülmesi daha doğru olabilecek konulardan zihni uzaklaştırmak olumlu sonuç verebilir.

Sonuç itibariyle MPK, özellikle profesyonel anlamda müzikle uğraşan kişilerin mesleki başarısını olumsuz etkileyebileceği gibi bir başa çıkma stratejisi geliştirmediği taktirde de ruhsal sağlı̆̆ını bozmada etken olabilecek bir kaygı durumudur. Müzik performansı sırasında ortaya çıkan bu kaygıyı azaltmak için beta-bloker, madde veya alkol kullanımı bu sorunu çözmekte uygun bir davranış değildir. Bu sebeple bu kaygı türünün ortaya çıkması durumunda erken müdahalede bulunulmalı, uygun spiritüel ve psikoterapik yaklaşımlarla uzman desteği alarak kaygıyla başa çıkma yolları araştırılmalıdır.

Bunlara ek olarak mesleki müzik eğitimi veren kurumlarda, MPK için müzik eğitimcilerinin bilgilendirilmeleri yerinde olabilir. Müzik eğitimcilerinin ve müzik öğretmeni adaylarının bu kaygı durumuyla başa çıkma yolları hakkında bilgilendirilmesi için üniversitelerin lisans programlarında MPK ile ilgili seminerler verilmesi önerilebilir. 


\section{Kaynaklar}

Akgün, A., Gönen, S. \& Aydın, M. (2007). İlköğretim fen ve matematik öğretmenliği öğrencilerinin kayg1 düzeylerinin bazı değişkenlere göre incelenmesi [Anxiety levels of elementary science and mathematics education students according to some variables]. Electronic Journal of Social Sciences, 6 (20), 283-299. Retrieved from http://dergipark.gov.tr/esosder/issue/6134/82271.

Allen, R. (2010). Free improvisation and performance anxiety among piano students. Unpublished Doctoral Thesis. Boston University Coolege of Fine Arts, Boston.

Bozanoğlu, İ. (2005). Bilişsel Davranışçı yaklaşıma dayalı grup rehberliğinin güdülenme, benlik saygısı, başarı ve sinav kaygisı düzeylerine etkisi [The effect of group guidance based on cognitive behavioral approach on motivation, self-esteem, achievement and test anxiety levels]. Ankara University Journal of Education Faculty, $38(1), 17-42$.

Büyüköztürk, Ş. (1997), Araştırmaya yönelik kaygı ölçeğinin geliştirilmesi [Development of anxiety scale for research]. Education Management, 3(4), 453-464.

Çırakoğlu, O. C. (2013). Sahnedeki düşman: Müzisyenlerde performans kaygısı üzerine bir gözden geçirme [The enemy on stage: A review of the performance anxiety in musicians].. Turkish Psychology Articles, 16 (32), 95-104.

Çimen, G. (2001). Konser kaygısı [Concert Anxiety]. Journal of Gazi Education Faculty, 21 (2), 125-133.

Çoban A. E. \& Karaman N. G. (2013). Üniversite öğrencilerinin umutsuzluk, kaygı ve ilişkilerle ilgili bilişsel çarpıtmalar. [University students cognitive distortions related to hopelessness, anxiety and relationships]. Journal of Cognitive Behavioral Psychotherapy and Research 2(2), 78-88.

Doğan, U. (2013). Ergenlerde performans kaygısını yordayan değişkenlerin modellenmesi ve buna yönelik psikoeğitim programının işlevselliği [Modeling of variables predicting performance anxiety in adolescents and functionality of psychoeducation program]. Unpublished Ph. D. dissertation. Sakarya University Institute of Educational Sciences.

Ellis, R. (1994). The study of second language acquisition, Oxford University Press, 1994.

Iş1k, E. (1996). Nevrozlar [Neuroses]. Ankara: Kent.

Green, B. \& Gallwey, T. (2015). Müziğin içsel oyunları (B. Tecimer, Çev.) [Inner games of music (B. Tecimer, Trans.) Ankara: Music Education.

Kavakçı, Ö., Güler, A. S. \& Çetinkaya, S. (2011). Sınav kaygısı ve ilişkili psikiyatrik belirtiler [Psychological symptoms related to exam anxiety]. Turkish Journal of Clinical Psychiatry, 14, 7-16.

Kenny, D. T. (2008). Music performance anxiety. A. Williamon (Ed.), International Handbook of Musicians' Health and Wellbeing. Oxford, UK: Oxford.

Papageorgi, I., Creech, A., \& Welch, G., (2011). Perceived performance anxiety in advanced musicians specializing in different musical genres. Psychology of Music. 41 (1), 18-41.

Salmon, P. G. (1990). A psychological perspective on musical performance anxiety: a review of the literature. Medical Problems of Performing Artists, 5(1), 2-11.

Salmon, P. G. \& Meyer, R. G. (1992). Coping with stesss and anxiety in musical performance. New York: Lexington Books.

Scovel T. (1978) The effect of affect on foreign language learning: A review of the anxiety research. Language Learning, 28 (1), 129-142.

Tokinan, B. Ö. (2013). Kenny müzik performans kaygısı envanterini Türkçe’ye uyarlama çalışması [Adaptation of Kenny music performance anxiety inventory to Turkish]. Ahi Evran Üniversity Journal of Kırşehir Education Faculty, 14 (1), 53-65.

Üldaş, İ. (2005), Öğretmen ve öğretmen adaylarına yönelik matematik kaygı ölçeği (MKÖ-Ö)'nın geliştirilmesi ve matematik kaygısına ilişkin bir değerlendirme [Development of mathematics anxiety scale for teachers and 
pre-service teachers and evaluation of math anxiety]. Published Masters Thesis. Marmara University Institute of Educational Sciences, Istanbul.

Yöndem, Z. D. (2012). Müzik öğrencilerinde algılanan performans kaygısının fiziksel, davranışsal ve bilişsel özellikleri: Nitel bir çalışma [Physical, behavioral and cognitive characteristics of perceived performance anxiety in music students: A qualitative study]. Education and Science. 37 (166), 181-194. 